\title{
Course corrections
}

\author{
If the US government chooses to bail out the nation's vehicle manufacturers, it must ensure that the \\ industry commits to the innovations required for future transportation.
}

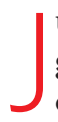
ust months after the US Congress approved $\$ 25$ billion in loan guarantees for the nation's vehicle manufacturers, the 'Big Three' companies are back in Washington asking for more. The loan guarantees are to help the firms retool their facilities and begin building vehicles with improved fuel efficiency. The latest request from General Motors, Ford and Chrysler is for another $\$ 25$ billion to help them ride out the current financial crisis.

The reception on Capitol Hill to the bail-out request has so far been frosty, and with good reason. These companies have systematically failed to acknowledge, let alone anticipate, the energy and business trends that are driving an increasingly globalized vehicle market. They have repeatedly fended off fuel-efficiency regulations that might have softened the blow of the recent energy crunch, and instead kept turning out the petrol-hungry sportutility vehicles that US consumers once embraced, but are now abandoning. This is just one of many mistakes in an outdated business model that has left the Big Three especially vulnerable to the current crisis.

Regardless, General Motors says it will run out of cash in a matter of weeks, and the other two aren't faring much better. As their collapse would only make a bad situation worse, the US government may have no choice but to intervene, just as it felt compelled to bail out Wall Street. This makes it all the more important that any federal rescue plan should be structured not as a short-term monetary fix, but as a chance for US vehicle makers to clear the slate and start anew. As president-elect Barack Obama correctly put it, the government should not be issuing "a bridge loan to nowhere".

In particular, the worst thing policy-makers could do is to raise the bail-out cash by raiding the $\$ 25$ billion in loan guarantees designated for the manufacturers' green retooling - as some in Congress have suggested. The global transportation sector is responsible for some

$13 \%$ of the world's greenhouse-gas emissions. Properly implemented, these loans could help turn that situation around.

Even more importantly, vehicle makers and policy-makers alike need to be open to radically new ways of doing business. To paraphrase Albert Einstein, we can't solve problems with the same thinking that created them in the first place. On page 436, for example, Nature looks at the prospects for electrification of the transport sector; one clear lesson is that innovation comes in many forms. As companies such as

"The US government should not be issuing a bridge loan to nowhere."

Better Place of Palo Alto, California, and Th!nk of Snarøya, Norway, illustrate, the barriers to new forms of transportation may not lie so much with the technology but with the way it is marketed. By simply leasing batteries and charging customers a monthly fee that includes all electric 'fuel', these companies hope to lower the upfront costs and give consumers the reliability that they want. A similar business model worked for mobile phones, why not for cars?

Whatever happens with that particular approach, electric vehicles increasingly look like a viable part of the solution to the transportation challenge. But getting there will require a multipronged approach involving battery manufacturers, vehicle manufacturers, electric utilities and governments. The good news is that utilities and vehicle companies understand this. In fact, some utilities are pondering the idea of jumpstarting the electric car market by ordering vehicles themselves. That is an idea that governments should consider as well.

All of this should be at the fore as the US government ponders investing in the vehicle industry. Government intervention might well be the catalyst for change - but new thinking is going to be required from everyone.

\section{A fruitless campaign}

\section{Another protracted fight over genetically modified crops in Africa will be costly and wasteful.}

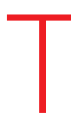

he global food crisis that came to the fore last spring may have been overshadowed by the global financial crisis that erupted this autumn, but it has certainly not been solved. That is one reason why many governments and philanthropic foundations are now looking to agricultural biotechnology to improve future food production. Despite the virulent opposition to genetically modified (GM) crops in some quarters, many believe that progress in areas such as drought-tolerant or nutritionally fortified plants could make a big difference in many of the poorest countries.
Indeed, environmentalists, policy-makers, scientists and industry representatives have been meeting both formally and informally over the past few years - first to establish a degree of common ground, and then to approach the trickier business of bridging some of their differences on the role of GM technology in agriculture.

A prime example is the work of the African Union's High-Level Panel on Modern Biotechnology, which was charged with charting a way forward in what have become known as Africa's GM wars. For well over a decade, companies such as Monsanto have sought to create African markets for GM crops such as insect-resistant Bt cotton, while against them have stood European environmental groups and not a few African political leaders, for whom multinational businesses evoke the spectre of colonialism. The two sides have waged a war in parliaments, in the media and even on the streets.

Fed up, the African Union eventually brought together a group 